EXPERIMENTAL STUDY

\title{
Mammary gland development and lactation are controlled by different glucocorticoid receptor activities
}

\author{
Holger M Reichardt, Kay Horsch ${ }^{1}$, Hermann-Josef Gröne ${ }^{2}$, Andrea Kolbus ${ }^{3}$, Hartmut Beug ${ }^{3}$, Nancy Hynes ${ }^{1}$ \\ and Günther Schütz \\ Division of Molecular Biology of the Cell I, German Cancer Research Center, Im Neuenheimer Feld 280, 69120 Heidelberg, Germany, \\ ${ }^{1}$ Friedrich Miescher Institute, 4002 Basel, Switzerland, ${ }^{2}$ Division of Cellular and Molecular Pathology, German Cancer Research Center \\ Im Neuenheimer Feld 280, 69120 Heidelberg, Germany and ${ }^{3}$ Research Institute of Molecular Pathology, Dr. Bohr-Gasse 7, 1030 Vienna, Austria \\ (Correspondence should be addressed to G Schütz, DKFZ (A0200), Im Neuenheimer Feld 280,69120 Heidelberg, Germany; Email: g.schuetz@dkfz.de)
}

\begin{abstract}
Objective: Regulation of physiological processes by glucocorticoids is achieved by binding to the glucocorticoid receptor (GR) and subsequent modulation of gene expression, either by DNA bindingdependent mechanisms or via protein-protein interaction with other transcription factors. The purpose of this study was to define the molecular mechanism of GR underlying the control of mammary gland development and lactation.

Design: To dissect the mechanism of GR action in the mammary gland, we used genetically modified mice carrying a DNA binding-defective GR. These mice retain the ability to regulate transcription by protein-protein interaction but fail to control gene expression by DNA binding-dependent mechanisms. Thus, they allow the study of the mode of GR action in vivo.

Methods: The development of the mammary gland and milk protein synthesis during lactation were studied using histological and biochemical methods.

Results: Our findings demonstrated that the lack of the DNA binding function of GR impairs the ductal development of the mammary gland in virgin females and that this can presumably be accounted for by reduced proliferation of epithelial cells. In contrast, lactating females have normally differentiated mammary glands and are fully capable of milk protein production. This is in good agreement with the demonstration that the DNA binding-defective GR is still able to interact with phosphorylated Stat5 proteins, suggesting that transcriptional regulation by protein-protein interaction forms the basis of glucocorticoid action in this process.

Conclusions: The present study has demonstrated that GR plays an important role in the mammary gland and that it uses different molecular modes of action to control development and milk protein synthesis.
\end{abstract}

European Journal of Endocrinology 145 519-527

\section{Introduction}

The adult mammary gland in the mouse is mainly composed of fat tissue with ducts and alveolar lobuli scattered throughout $(1,2)$. Compared with humans the organization of the mouse mammary gland is less complex, lacking dense connective tissue and having simpler lobules and little periepithelial stroma. Postnatal development of the mammary gland is a dynamic process involving extensive epithelial cell proliferation, penetration of the ductal epithelia into the adipose fat pad and arborization. Usually by the age of 10 weeks the stroma is completely infiltrated by the ductal system. Mammogenesis further proceeds from buds and is achieved by lengthening of the primary ducts, bifurcation of terminal end buds and secondary lateral branching. Terminal branches are formed around the third month of age, finally growing alveolar buds. Myoepithelial cells form a sleeve around the primary ducts while becoming discontinuous around secondary and tertiary ducts. It is generally accepted that a variety of hormones and growth factors are involved in mammogenesis $(1,3)$. Using knock-out mice it can be shown that oestrogens are required for the formation of the ductal system after birth (4) whereas progesterone promotes arborization and the development of the lobuloalveolar system during pregnancy (5). Furthermore, analysis of prolactin receptor-deficient mice demonstrated that signalling by prolactin is required for normal postpubertal development of the mammary gland $(6,7)$. Finally, analysis of the natural mutant op which lacks colony-stimulating factor- 1 revealed an important contribution of this growth factor to ductal growth during pregnancy and lactation (1). 
Glucocorticoids (GC) play an important role in a variety of processes, involving the development of organs, control of energy homeostasis, regulation of the immune system, adaption to stress and modulation of behaviour (8). The majority of GC activities are mediated by the glucocorticoid receptor (GR), a member of the steroid hormone receptor superfamily, by activation or repression of gene expression (9). GR acts as a ligand-dependent transcription factor and controls transcription either through homodimeric binding to glucocorticoid response elements (GREs) or via DNA binding-independent protein-protein interaction with other transcription factors such as AP-1, nuclear factor$\kappa \mathrm{B}(\mathrm{NF}-\kappa \mathrm{B})$ or Stat5 (10-14). These two molecular modes of action can be efficiently distinguished using $\mathrm{GR}^{\mathrm{dim}}$ mice, a mutant mouse strain which was generated by a knock-in approach using the Cre/loxP system (15). These mice carry the point mutation A458T in the D loop, one of the dimerization domains of the receptor, which selectively abrogates homodimerization and subsequent DNA binding of GR (16). In contrast, regulation of gene expression by protein-protein interaction with other transcription factors such as AP-1 and NF- $\mathrm{kB}$ remains intact $(17,18)$.

Milk protein synthesis in the mammary gland has been an intensively studied paradigm for the integration of peptide and steroid hormone signalling in the control of gene expression. In particular, it has been found that GC and prolactin act synergistically during induction of the $\beta$-casein and other milk protein genes in mammary epithelial cells (19). This synergy has been explained by protein-protein interaction of GR with Stat5, a transcription factor which becomes activated by phosphorylation after binding of prolactin to its receptor $(13,14,20)$. Further support for this model comes from promoter analyses which revealed binding sites for Stat5 but no palindromic GRE in the $\beta$-casein gene (21). Additional experiments demonstrated that the transcriptional synergy of GR and Stat 5 is, at least in part, due to an enhancement of the Stat5 DNA binding activity by GR (22). Taken together, these findings suggest that GR plays an important role during lactation by controlling gene expression through protein-protein interaction with Stat5 in the absence of homodimeric DNA binding.

Besides its role in lactation, little else is known about the function of GR in the mammary gland. It was shown that GR provides a survival signal for mammary epithelial cells in culture (23) and that GC negatively interfere with mammary carcinogenesis (24). However, control of ductal and lobuloalveolar development by GR has not been studied previously. Furthermore, most data on the regulation of milk protein synthesis were obtained in vitro. In this study, we have used GR ${ }^{\text {dim }}$ mice to study the molecular mechanism used by GR in vivo. We have identified mammary gland development as a process involving DNA binding-dependent transcriptional regulation by GR. In contrast, milk protein synthesis was found to be mediated by proteinprotein interaction of phosphorylated Stat 5 with GR. Thus, different activities of GR are responsible for the control of these two processes.

\section{Materials and methods}

\section{Animal experimentation}

$\mathrm{GR}^{\mathrm{dim}}$ mice and wild-type controls were obtained as previously described (15). Females of both genotypes used within the same experiment were housed together for at least 4 weeks. Mice were killed using $\mathrm{CO}_{2}$ and subsequently tissues and blood were isolated for further analysis. All animal experiments were conducted according to the highest institutional and international standards.

\section{Whole-mount stainings}

Mammary glands were dissected and fixed in Tellyesniczky's fixative for $24 \mathrm{~h}$ on glass slides. Tissues were defatted in acetone, hydrated through an ascending ethanol series and stained in an iron-haematoxylin solution for $90 \mathrm{~min}$. After dehydration through a descending ethanol series and several changes of toluol, the slides were stored in methyl salicylate and photographed for documentation.

\section{Histology and immunohistochemistry}

Immuohistochemistry was carried out on $5 \mu \mathrm{m}$ sections of paraffin-embedded tissues after microwave pretreatment. Actin was demonstrated by a mouse monoclonal smooth muscle actin-specific antibody (Sigma, Deisenhofen, Germany) diluted 1:400, the proliferation marker Ki-67 by a rabbit anti-mouse Ki67 antibody (Dianova, Hamburg, Germany). Secondary antibodies were biotin-labelled goat anti-mouse or antirabbit IgGs diluted 1:250 (Jackson Immuno Research, Philadelphia, PA, USA). Horseradish-peroxidase streptavidin (Vector Laboratories, Alexis, Grünberg, Germany) was diluted 1:200. All incubation steps were performed at $22{ }^{\circ} \mathrm{C}$, 3-amino-9-ethylcarbazole was taken as a substrate.

Quantification of ductal structures was performed by counting 10 microscopic fields (using a $10 \times$ objective) per slide. Quantification of Ki-67 positive cells was achieved by counting positively stained cells in 10 medium-sized ducts per microscopic field and 10 fields per slide. The number of animals per group was five to seven, values are given as the means \pm s.D., statistical significance was determined using Student's t-test.

\section{Immunoprecipitation and Western blotting}

Whole cell extracts were obtained by solubilizing cells in NP-40 extraction buffer ( $50 \mathrm{mM}$ Tris, pH 7.5, $5 \mathrm{mM}$ 
EDTA, 1 mM EGTA, $120 \mathrm{mM} \mathrm{NaCl,} \mathrm{1 \%} \mathrm{NP-40,} 2$ mM sodium orthovanadate, $20 \mathrm{mM} \beta$-glycerophosphate, $50 \mathrm{mM}$ sodium fluoride, $2 \mathrm{mM}$ phenylmethylsulfonyl fluoride, $5 \mu \mathrm{g} / \mathrm{ml}$ leupeptin, $5 \mu \mathrm{g} / \mathrm{ml}$ aprotinin) for 5 min on ice. The lysates were cleared by centrifugation at $16000 \mathrm{~g}$ for $15 \mathrm{~min}$. For immunoprecipitations, equal amounts of protein were incubated with specific antibodies for $1 \mathrm{~h}$ on ice. Immune complexes were collected with protein $\mathrm{A}$-Sepharose by rotating the complexes for $30 \mathrm{~min}$ at $4{ }^{\circ} \mathrm{C}$, washing three times with lysis buffer and once with TNE buffer $(50 \mathrm{mM}$ Tris, $140 \mathrm{mM} \mathrm{NaCl}, 5 \mathrm{mM}$ EDTA). Precipitated proteins were subjected to SDS-polyacrylamide gel electrophoresis and blotted onto polyvinylidene difluoride membranes. After blocking with $10 \%$ horse serum in TTBS (50 mM Tris, pH 7.5, $150 \mathrm{mM} \mathrm{NaCl,} \mathrm{0.1 \%}$ Tween 20) membranes were probed with specific antibodies. Proteins were visualized with peroxidasecoupled secondary antibody using the ECL detection system (Amersham Pharmacia Biotech, Little Chalfont, Bucks, UK). Stripping of membranes was performed in SDS buffer (62.5 mM Tris, pH 6.8, 2\% SDS, $100 \mathrm{mM}$ $\beta$-mercaptoethanol) for $30 \mathrm{~min}$ at $60{ }^{\circ} \mathrm{C}$. After the stripping, membranes were washed with TTBS and reprobed with the indicated antibodies. The antibodies used were: rabbit polyclonal antiserum raised against a purified rat GR fragment (25), anti-Stat5a and -Stat5b sera raised in rabbits against specific C-terminal peptides (26), polyclonal antiserum against mouse milk raised by injection of skimmed mouse milk into rabbits (27) and phosphotyrosine-specific monoclonal antibody (28).

\section{RNA isolation and Northern blot analysis}

Total RNA was extracted using Trizol (Gibco BRL, Karlsruhe, Germany) according to the manufacturer's instructions. Ten micrograms of total RNA were resolved by gel electrophoresis and transferred to a nylon membrane. rRNA was stained on the filters with methylene blue (29) to assess RNA loading and transfer. Hybridization was performed as previously described (30). The mouse cDNAs of $\beta$-casein, $\alpha$ lactalbumin and whey acidic protein (WAP) were labelled with ${ }^{32} \mathrm{P}$-dATP by a random primed labelling kit (Roche Molecular Biochemicals, Mannheim, Germany) and used as probes. Levels of specific RNA were measured in a Molecular Dynamics Phosphoimager.

\section{Hormone determination}

Serum was obtained by centrifugation of freshly isolated EDTA blood at 5000 r.p.m. for $10 \mathrm{~min}$. Hormones were measured using commercially available RIA kits (ICN Diagnostics, Meckenheim, Germany and Amersham Pharmacia Biotech) according to the manufacturer's instructions.

\section{Results and discussion}

\section{The DNA binding-dependent function of GR is required for full ductal development of the virgin mammary gland}

To study the role of GC in the development of the mammary gland, whole-mount stainings and histological analyses were performed using virgin female mice of 10 and 22 weeks of age. Infiltration of the mammary fat pad with the ductal tree is usually achieved in female mice 10 weeks after birth. By 22 weeks of age alveolar buds have also formed at the ends of the ductal tree. Whole-mount stainings performed on the fourth inguinal mammary gland of 10-week-old virgin females revealed considerably reduced ductal side branching in $\mathrm{GR}^{\mathrm{dim}}$ mice as compared with wildtype controls (Fig. 1A and B). The mammary gland of 22-week-old females showed even more pronounced differences. In addtion to the reduced arborization of the ductal tree, mutant mice almost completely lack alveolar buds (Fig. 1C and D). In contrast, at the tips of most ducts structures resembling terminal end buds remain. Counting of ductal structures in haematoxylin-eosin-stained sections confirmed the impaired development of the mammary gland in $\mathrm{GR}^{\mathrm{dim}}$ mice (Fig. 1E and F). In 22-week-old female $\mathrm{GR}^{\mathrm{dim}}$ mice a significant reduction of ductal structures by more than $50 \%$ was observed compared with wild-type controls (wild-type $=182 \pm 38, \mathrm{GR}^{\mathrm{dim}}=89 \pm 33, P<0,02$, see Materials and methods). This demonstrates that GR and namely its DNA binding-dependent activity is required for normal ductal development of the virgin mammary gland.

\section{Proliferation of mammary epithelial cells is impaired in GR ${ }^{\text {dim }}$ mice}

To study the defect in mammogenesis in more detail, we quantified proliferation of epithelial cells by immunohistochemistry. Paraffin sections of the fourth inguinal mammary gland were stained with an antibody against the proliferation marker Ki-67 and positive cells were counted (see Materials and methods). Interestingly, in both 10- and 22-week-old virgin GR ${ }^{\mathrm{dim}}$ females a marked reduction in the number of Ki-67 positive cells was observed as compared with wild-type controls, indicating an impaired proliferation of epithelial cells (Fig. 2A and B and data not shown). At 10 weeks of age, proliferation was reduced by $90 \%$, at 22 weeks by $70 \%$ (Fig. 2E). Thus it appears that GR exerts a positive influence on the proliferation of epithelial cells, presumably explaining the impaired development of the mammary gland in GR ${ }^{\mathrm{dim}}$ mice.

The presence of myoepithelial cells has been implicated in the development of the ductal tree in the mammary gland (31). We therefore studied the presence of myoepithelial cells in 10- and 22-week-old 

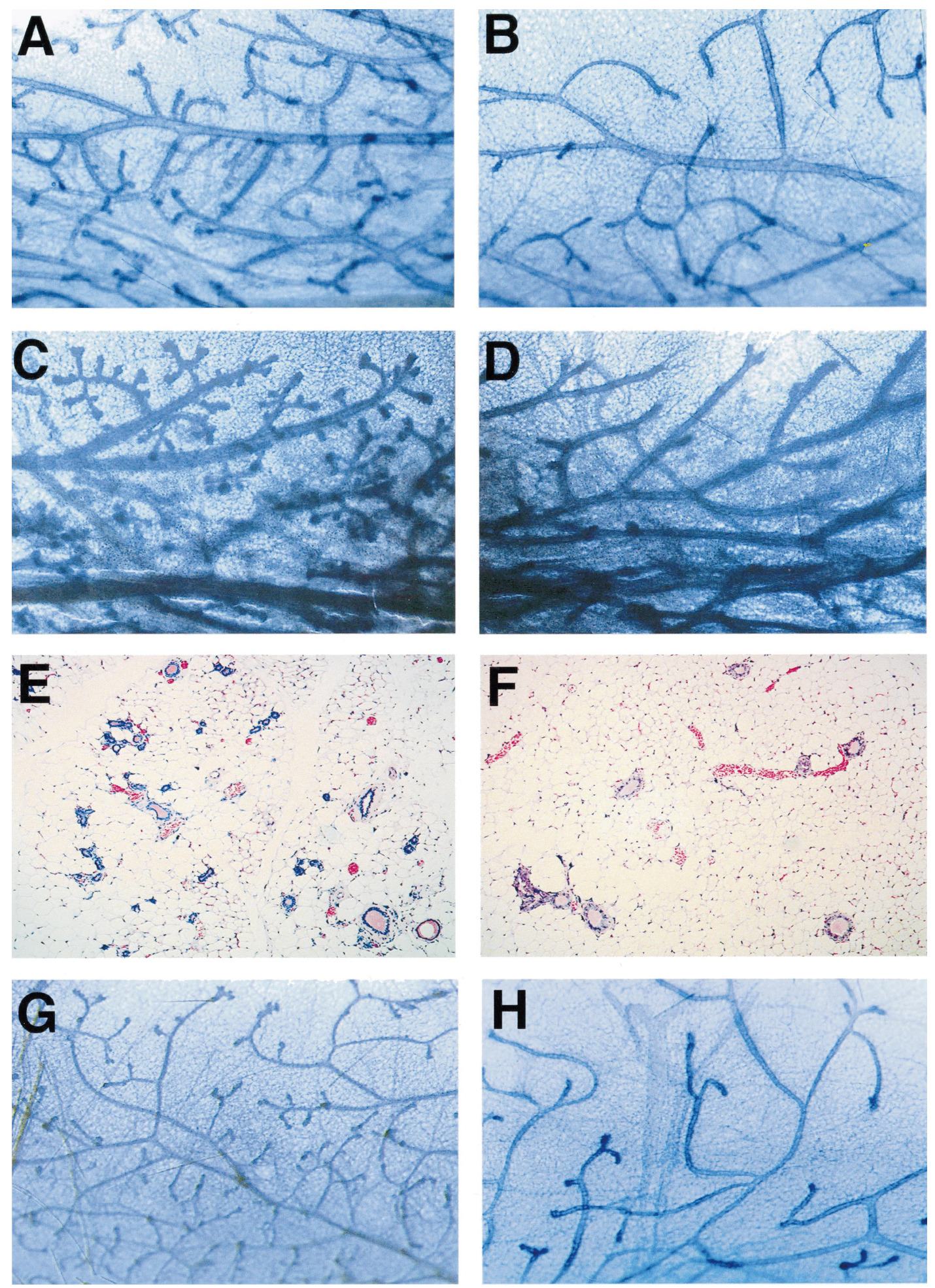

Figure 1 Anatomical and histological analysis of the fourth inguinal mammary gland isolated from wild-type $(A, C, E$ and $G)$ and GR ${ }^{\text {dim }}$ mice (B, D, F and H). ( $A$ and $B$ ) Whole-mount stainings of the mammary gland from 10-week-old virgin females. (C and $D)$ Whole-mount stainings of the mammary gland from 22-week-old virgin females. ( $E$ and $F$ ) Haematoxylin-eosin staining of paraffin sections of the mammary gland of 22-week-old virgin females. ( $G$ and $H)$ Whole-mount stainings of the mammary gland from 10-week-old virgin females crossed onto a $\mathrm{p} 53^{-1-}$ background. 

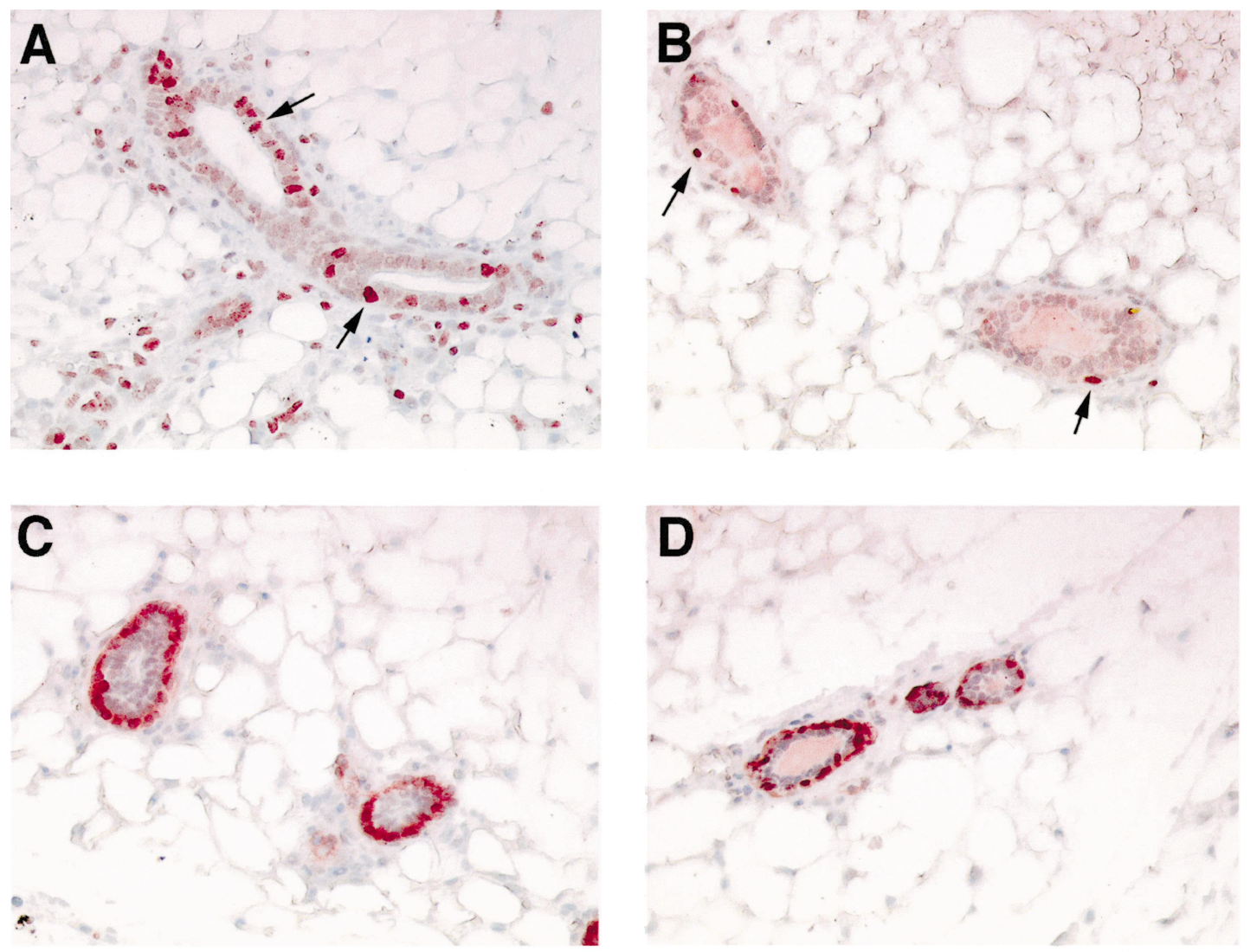

$\mathbf{E}$

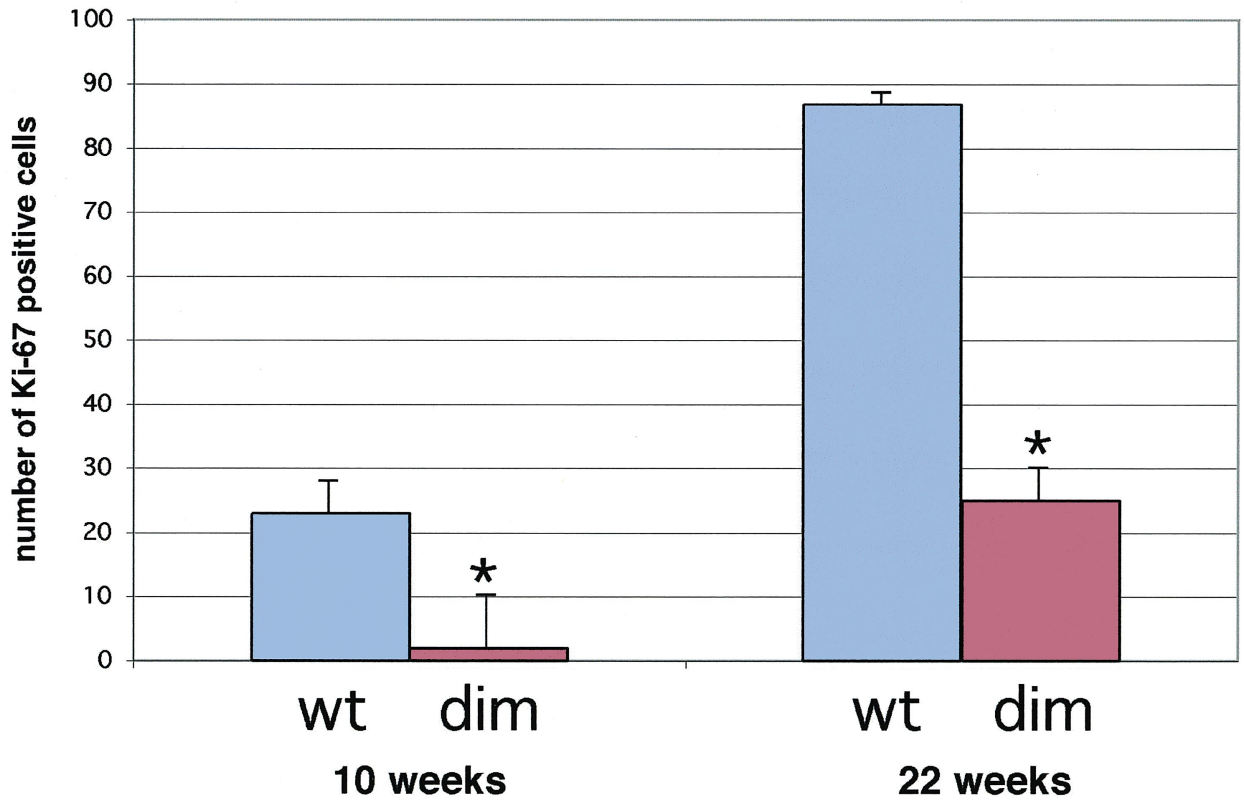

Figure 2 Immunohistochemical analysis of epithelial proliferation in 22-week-old virgin female wild-type (A and $C)$ and $\mathrm{GR}^{\text {dim }}$ mice $(B$ and $D)$. ( $A$ and $B)$ Staining of paraffin sections of the fourth inguinal mammary gland with a Ki-67 antibody. Positively labelled cells are marked by an arrow. (C and D) Staining of paraffin sections of the fourth inguinal mammary gland with a smooth muscle actin antibody. (E) Quantification of Ki-67 positive cells as described in Materials and methods. 
virgin females taking expression of actin as a marker. Using immunohistochemistry, we demonstrated a normal presence of myoepithelial cells in virgin females of both genotypes (Fig. 2C and D). Thus, lack of these cells can be excluded as a potential source for the observed developmental defect of the mammary gland in $\mathrm{GR}^{\mathrm{dim}}$ mice.

p53-dependent signalling has been demonstrated to be involved in certain aspects of mammary gland development $(32,33)$. In particular, $\mathrm{p} 53^{-1-}$ mice show reduced levels of apoptosis in the terminal end buds of the mammary gland although they lack a general impairment of ductal development (33). Interestingly, mutual interference between the transcriptional activities of GR and p53 has been reported (34-36), suggesting a potential link between signalling via these two molecules. To study whether p53-mediated regulation contributes to the observed impairment of mammary gland development in $\mathrm{GR}^{\mathrm{dim}}$ mice, we crossed them onto a p $53^{-1-}$ background. In agreement with previous reports, no defect in ductal development was observed in 10-week-old virgin $\mathrm{p} 53^{-1-}$ females (33). Furthermore, $\mathrm{GR}^{\mathrm{dim}}$ mice exibited the same defect in ductal side branching in the absence of p53 as in its presence (compare Fig. $1 \mathrm{G}$ and $\mathrm{H}$ with Fig. $1 \mathrm{~A}$ and $1 \mathrm{~B}$ ). This indicates that GR-mediated modulation of p53dependent processes is not related to the defect in mammary gland development as observed in $\mathrm{GR}^{\text {dim }}$ mice.

\section{The effect of the $\mathrm{GR}^{\text {dim }}$ mutation on mammary gland development is direct}

Wild-type and mutant GR are present in almost every cell type of the organism including epithelial and stromal cells of the mammary gland, hypothalamus, pituitary and reproductive organs (data not shown). Consequently, GR might influence mammogenesis by two potential mechanisms. First, GR could act directly in epithelial or stromal cells of the mammary gland. Alternatively, neuroendocrine regulation might be affected, thus leading to altered levels in reproductive hormones such as oestrogen, progesterone or prolactin.

As a first step towards the dissection of direct and indirect GC effects on mammary gland development, we analysed the levels of reproductive hormones in 10week-old virgin female mice. Whereas, at this stage, the development of the mammary gland is clearly impaired, no significant difference in oestrogen and progesterone levels could be detected (Table 1). Prolactin serum levels were below the limit of detection of the assay, thus precluding a definitive conclusion. However, it should be noted that mRNA levels of prolactin are increased in the pituitary of GR $^{\text {dim }}$ mice (15). This suggests that, at least, diminished prolactin signalling is unlikely to account for the impaired development of the mammary gland in mutant virgin females. Taken
Table 1 Levels of $17 \beta$-oestradiol and progesterone in 10-week-old virgin wild-type and $\mathrm{GR}^{\text {dim }}$ females (during pro-oestrus) $(n=5)$.

\begin{tabular}{lcc}
\hline & Wild-type & GR $^{\text {dim }}$ \\
\hline $17 \beta$-Oestradiol & $67 \pm 12 \mathrm{pg} / \mathrm{ml}$ & $88 \pm 19 \mathrm{pg} / \mathrm{ml}$ \\
Progesterone & $58 \pm 34 \mathrm{ng} / \mathrm{ml}$ & $27 \pm 4 \mathrm{ng} / \mathrm{ml}$ \\
\hline
\end{tabular}

together, the defect observed in $\mathrm{GR}^{\mathrm{dim}}$ mice appears to be the result of a direct action of GR in the mammary gland.

\section{Lactation in $G^{\text {dim }}$ mice is unimpaired}

Given the phenotype of virgin $\mathrm{GR}^{\mathrm{dim}}$ females, we analysed the morphology of the mammary gland in lactating mice, killed 3 days after parturition. Although mammary glands were smaller in mutant females, normal formation of alveoli during pregnancy could be demonstrated, both by whole-mount staining (Fig. 3A and B) and histology (Fig. 3C and D). Furthermore, staining of the sections with an antibody against Ki-67 failed to demonstrate differences in the proliferation of epithelial cells in the mammary gland of $\mathrm{GR}^{\mathrm{dim}}$ females (Fig. 3C and D). In line with the absence of severe alterations in lactating females, $\mathrm{GR}^{\mathrm{dim}}$ mice can have offspring and normally succeed in nursing their pups. We conclude that, during pregnancy and lactation, the lack of the DNA binding function of GR can be compensated for by other mechanisms.

GC play an important function during lactation by synergistically acting with prolactin to stimulate expression of milk protein genes (37). It has previously been demonstrated in vitro that GR interacts with Stat5 to induce $\beta$-casein gene expression (13). Using ectopically expressed chimeras of the GR it was shown that its DNA binding domain is not necessary for transcriptional induction of the $\beta$-casein promoter (14). This suggests that GR may act as a co-activator of Stat5, independent of its DNA binding function. Furthermore, a complex between GR and Stat5 has been observed in cultured mammary epithelial cells and in various organs, including the mammary gland (20). These results prompted us to examine the association of $\mathrm{GR}^{\mathrm{dim}}$ and Stat5 in extracts made from lactating mammary glands of $\mathrm{GR}^{\mathrm{dim}}$ females. To this end, GR was immunoprecipitated with a specific antiserum. Probing the immune complexes with a Stat5a specific antiserum revealed that the two proteins were associated to an equivalent extent in extracts made from mammary glands of wild-type and $\mathrm{GR}^{\mathrm{dim}}$ females (Fig. 4B lower panel). The activation status of both Stat5a and Stat5b was also equivalent in wildtype and mutant mammary glands, as shown by probing the Stat 5 immunoprecipitates with a phosphotyrosine specific antiserum (Fig. 4B upper panels). These results correlate well with the finding that the 

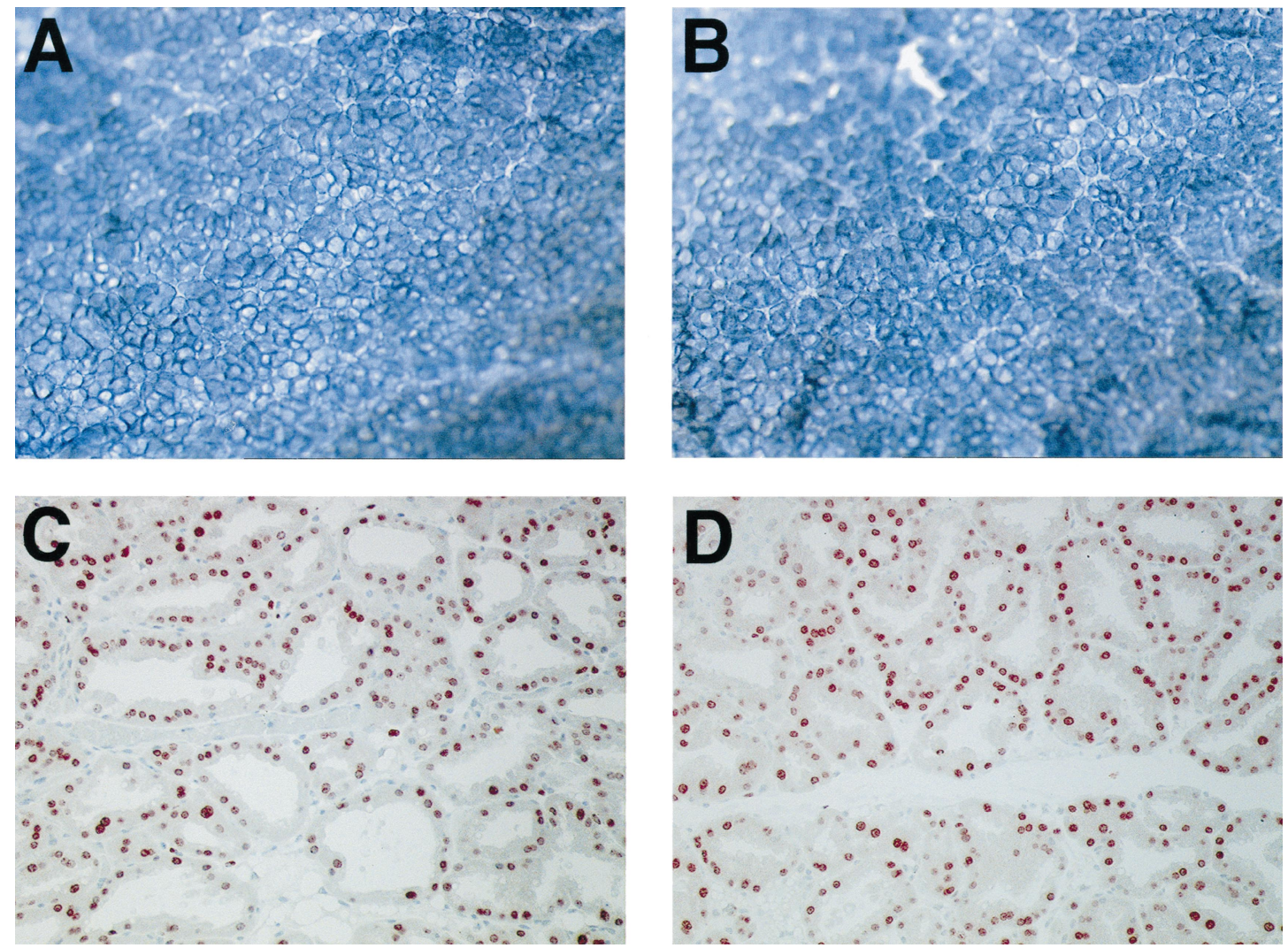

Figure 3 Anatomical and immunohistochemical analysis of the fourth inguinal mammary gland isolated from lactating wild-type (A and $C)$ and $G R^{\operatorname{dim}}$ mice (B and $D$ ). (A and $B$ ) Whole-mount stainings of the mammary gland. (C and D) Staining of paraffin sections of the mammary gland with a Ki-67 antibody.

A

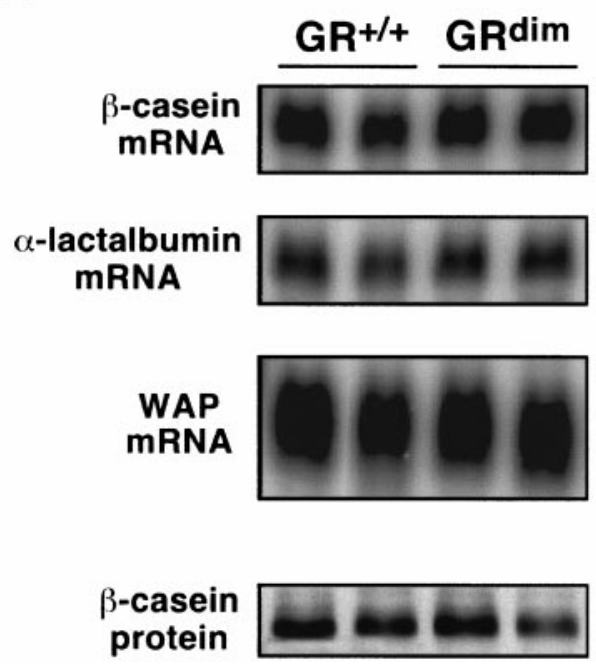

B
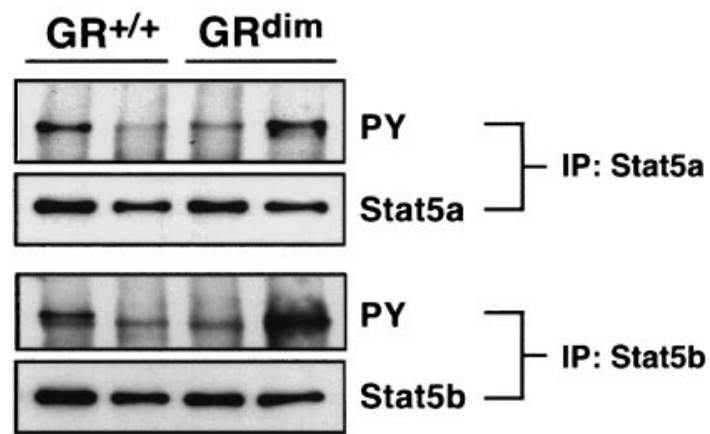

PY

Stat5b

IP: Stat5b

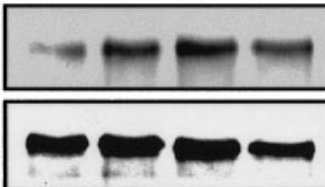

Stat5a<smiles>[101InH2]</smiles>

Figure 4 Analysis of milk protein sythesis in lactating wild-type and GR ${ }^{\text {dim }}$ females. (A) mRNA expression (Northern blot) of $\beta$-casein, $\alpha$-lactalbumin and WAP and protein expression (Western blot) of $\beta$-casein in mammary gland extracts of lactating females. (B) Western blot analysis of extracts from mammary glands of lactating females after immunoprecipitations (IP) using antibodies specific for Stat5a, Stat5b or GR. The resulting material was probed for phosphotyrosine (pTyr; PY), Stat5a, Stat5b and GR. 
level of milk protein expression was equivalent in all the lactating mammary glands (Fig. 4A). This was true not only for $\beta$-casein but also for $\alpha$-lactalbumin and WAP. Thus, the DNA binding-dependent function of GR is not required for milk protein expression in lactating mammary glands.

\section{Conclusions}

GR plays an important role in many physiological processes. With regard to the mammary gland it is known that GR is involved in the control of milk protein synthesis in vitro but an effect on ductal development has not yet been demonstrated. Here we have shown that the DNA binding-dependent function of GR is a prerequisite for normal development of the virgin mammary gland. This presumably proceeds via a direct effect of GR on the epithelial cells by enhancing proliferation. However, a lack of myoepithelial cells, a contribution of p53-dependent signalling or a reduction in reproductive hormones could be excluded as potential causes for the impaired ductal development of the mammary gland. In contrast, the DNA binding function of GR can be dispensed with for normal lobuloalveolar development and lactation. Interestingly, milk protein synthesis is also not affected by the absence of DNA binding by GR, suggesting that in vivo expression of genes such as $\beta$-casein may be mediated by protein-protein interaction of GR with Stat5. In the future, the generation and analysis of mammary glandspecific GR knock-out mice will allow for the further addressing of the role of GR in the production of milk proteins. Taken together, these observations suggest that it may be possible to selectively influence these processes by more specific GR ligands, specifically acting via one of the two modes of action of GR.

\section{Acknowledgements}

We would like to thank Heike Glaser, Nadine Sold, Gabi Stengl and Iris Moll for expert technical assitance. This work was supported by the 'Fonds der Chemischen Industrie', the European Community through grant PL 96 0179, the Bundesministerium für Bildung und Forschung through the HGP grant $01 \mathrm{KW}$ 9606/7, the Alexander von Humboldt-Stiftung, the VolkswagenStiftung and Boehringer Ingelheim.

\section{References}

1 Hennighausen L \& Robinson GW. Think globally, act locally: the making of a mouse mammary gland. Genes and Development 1998 $12449-455$.

2 Robinson GW, Hennighausen L \& Johnson PF. Side-branching in the mammary gland: the progesterone-Wnt connection. Genes and Development 200014 889-894.

3 Imagawa W, Bandyopadhyay GK \& Nandi S. Regulation of mammary epithelial cell growth in mice and rats. Endocrine Reviews 199011 494-523.
4 Korach KS, Couse JF, Curtis SW, Washburn TF, Lindzey J, Kimbro KS et al. Estrogen receptor gene disruption: molecular characterization and experimental and clinical phenotypes. Recent Progress in Hormone Research 199651 159-186.

5 Lydon JP, DeMayo FJ, Funk CR, Mani SK, Hughes AR \& Montgomery CA Jr et al. Mice lacking progesterone receptor exhibit pleiotropic reproductive abnormalities. Genes and Development $199592266-2278$.

6 Bartke A. Role of growth hormone and prolactin in the control of reproduction: what are we learning from transgenic and knock-out animals?. Steroids 199964 598-604.

7 Brisken C, Kaur S, Chavarria TE, Binart N, Sutherland RL, Weinberg RA et al. Prolactin controls mammary gland development via direct and indirect mechanisms. Developmental Biology 1999210 96-106.

8 Miller WL \& Blake Tyrrel J. The adrenal cortex. In Endocrinology and Metabolism, pp 555-711. Eds P Felig et al. New York: McGraw-Hill Inc., 1995.

9 Beato M, Herrlich P \& Schütz G. Steroid hormone receptors: many actors in search of a plot. Cell 199583 851-857.

10 Reichardt HM \& Schütz G. Glucocorticoid signalling - multiple variations of a common theme. Molecular and Cellular Endocrinology $1998 \mathbf{1 4 6} 1-6$.

11 Göttlicher M, Heck S \& Herrlich P. Transcriptional cross-talk, the second mode of steroid hormone receptor action. Journal of Molecular Medicine 199876 480-489.

12 De Bosscher K, Schmitz ML, Vanden Berghe W, Plaisance S, Fiers W \& Haegeman G. Glucocorticoid-mediated repression of nuclear factor-kappaB-dependent transcription involves direct interference with transactivation. PNAS 199794 13504-13509.

13 Stöcklin E, Wissler M, Gouilleux F \& Groner B. Functional interactions between Stat5 and the glucocorticoid receptor. Nature $1996383726-728$.

14 Stöcklin E, Wissler M, Moriggl R \& Groner B. Specific DNA binding of Stat5, but not of glucocorticoid receptor, is required for their functional cooperation in the regulation of gene transcription. Molecular and Cellular Biology 199717 6708-6716.

15 Reichardt HM, Kaestner KH, Tuckermann J, Kretz O, Wessely O, Bock R et al. DNA Binding of the glucocorticoid receptor is not essential for survival. Cell 199893 531-541.

16 Heck S, Kullmann M, Gast A, Ponta H, Rahmsdorf HJ, Herrlich P et al. A distinct modulating domain in glucocorticoid receptor monomers in the repression of activity of the transcription factor AP-1. EMBO Journal 199413 4087-4095.

17 Heck S, Bender K, Kullmann M, Göttlicher M, Herrlich P \& Cato ACB. IкB $\alpha$ independent downregulation of NF- $\mathrm{KB}$ activity by glucocorticoid receptor. EMBO Journal 199716 4698-4707.

18 Tuckermann JP, Reichardt HM, Arribas R, Richter KH, Schütz G \& Angel P. The DNA binding-independent function of the glucocorticoid receptor mediates repression of AP-1-dependent genes in skin. Journal of Cell Biololgy 1999 147 1365-1370.

19 Groner B \& Gouilleux F. Prolactin-mediated gene activation in mammary epithelial cells. Current Opinion in Genetics and Development 19955 587-594.

20 Cella N, Groner B \& Hynes NE. Characterization of Stat5a and Stat $5 \mathrm{~b}$ homodimers and heterodimers and their association with the glucocortiocoid receptor in mammary cells. Molecular and Cellular Biology 199818 1783-1792.

21 Rosen JM, Zahnow C, Kazansky A \& Raught B. Composite response elements mediate hormonal and developmental regulation of milk protein gene expression. Biochemical Society Symposium $199863101-113$.

22 Wyszomierski SL, Yeh J \& Rosen JM. Glucocorticoid receptor/ signal transducer and activator of transcription 5 (STAT5) interactions enhance STAT5 activation by prolonging STAT5 DNA binding and tyrosine phosphorylation. Molecular Endocrinology 199913 330-343.

23 Moran TJ, Gray S, Mikosz CA \& Conzen SD. The glucocorticoid receptor mediates a survival signal in human mammary epithelial cells. Cancer Research 200060 867-872. 
24 Zhu Z, Jiang W \& Thompson HJ. Effect of corticosterone administration on mammary gland development and p27 expression and their relationship to the effects of energy restriction on mammary carcinogenesis. Carcinogenesis 1998 19 2101-2106.

25 Hoeck W, Rusconi S \& Groner B. Down-regulation and phosphorylation of glucocorticoid receptors in cultured cells Investigations with a monospecific antiserum against a bacterially expressed receptor fragment. Journal of Biological Chemistry $198926414396-14402$.

26 Wartmann M, Cella N, Hofer P, Groner B, Liu X, Hennighausen L et al. Lactogenic hormone activation of Stat 5 and transcription of the beta-casein gene in mammary epithelial cells is independent of p42 ERK2 mitogen-activated protein kinase activity. Journal of Biological Chemistry 1996271 31863-31868.

27 Merlo GR, Venesio T, Taverna D, Marte BM, Callahan R \& Hynes NE. Growth suppression of normal mammary epithelial cells by wild-type p53. Oncogene 19949 443-453.

28 Druker BJ, Mamon HJ \& Roberts TM. Oncogenes, growth factors, and signal transduction. New England Journal of Medicine 1989 321 1383-1391.

29 Herrin DL \& Schmidt GW. Rapid, reversible staining of northern blots prior to hybridization. Biotechniques $1988 \mathbf{6} 196-197$, 199-200.

30 Ziegler A, Knesel J, Fabbro D \& Nagamine Y. Protein kinase C down-regulation enhances cAMP-mediated induction of urokinase-type plasminogen activator mRNA in LLC-PK1 cells. Journal of Biological Chemistry $199126621067-21074$.

31 Sternlicht MD, Lochter A, Sympson CJ, Huey B, Rougier JP Gray JW et al. The stromal proteinase MMP3/stromelysin-1 promotes mammary carcinogenesis. Cell 199998 137-146.
32 Li B, Greenberg N, Stephens LC, Meyn R, Medina D \& Rosen JM. Preferential overexpression of a $172 \mathrm{Arg} \rightarrow$ Leu mutant p53 in the mammary gland of transgenic mice results in altered lobuloalveolar development. Cellular Growth and Differentiation 1994 5 711-721.

33 Humphreys RC, Krajewska M, Krnacik S, Jaeger R, Weiher H, Krajewski S et al. Apoptosis in the terminal endbud of the murine mammary gland: a mechanism of ductal morphogenesis. Development 1996122 4013-4022.

34 Yu C, Yap N, Chen D \& Cheng S. Modulation of hormonedependent transcriptional activity of the glucocorticoid receptor by the tumor suppressor p53. Cancer Letters $1997 \mathbf{1 1 6}$ 191-196.

35 Maiyar AC, Phu PT, Huang AJ \& Firestone GL. Repression of glucocorticoid receptor transactivation and DNA binding of a glucocorticoid response element within the serum/glucocorticoid-inducible protein kinase (sgk) gene promoter by the p53 tumor suppressor protein. Molecular Endocrinology 199711 312-329.

36 Sengupta S, Vonesch JL, Waltzinger C, Zheng H \& Wasylyk B. Negative cross-talk between p53 and the glucocorticoid receptor and its role in neuroblastoma cells. EMBO Journal 200019 6051-6064.

37 Doppler W, Groner B \& Ball RK. Prolactin and glucocorticoid hormones synergistically induce expression of transfected rat beta-casein gene promoter constructs in a mammary epithelial cell line. PNAS 198986 104-108.

Received 14 February 2001

Accepted 28 June 2001 